\title{
FOREST RESTORATION PROGRESS AND LESSONS LEARNED IN GUNUNG PALUNG NATIONAL PARK, INDONESIA
}

\author{
Fawzi $\mathrm{NI}^{1, *}$, Helms J ${ }^{2}$, Emerson $\mathrm{A}^{3} \&$ Wibawanto $\mathrm{MA}^{4}$ \\ ${ }^{1}$ Alam Sehat Lestari, Sukadana, West Kalimantan, Indonesia 78852 \\ ${ }^{2}$ Kellogg Biological Station, Michigan State University, Hickory Corners, Michigan 49060, USA \\ ${ }^{3}$ Health in Harmony, Portland, Oregon 97214, USA \\ ${ }^{4}$ Ministry of Environment and Forestry, Jakarta, Indonesia 13410 \\ *nurul.ihsan.f@mail.ugm.ac.id
}

Submitted June 2019; accepted November 2019

\begin{abstract}
Restoring forests, especially within deforested or degraded protected areas, is critical to prevent global biodiversity loss and climate change. In this article, we explore the current conditions and progress of forest restoration in Gunung Palung National Park in Indonesian Borneo. The aim of this research was to review forest restoration projects and their success in the park, and to analyse lessons learned from those projects. From 2009 till 2018, nearly 5000 ha of damaged forest in Gunung Palung National Park were replanted, but with only a $1 \%$ restoration success rate. The main reason for failed restoration is wildfire. We found four issues that should be resolved in forest restoration projects: fire management, weed management, cost calculation and defining an appropriate restoration strategy. Restoration projects in the park have estimated the price per seedling at around USD0.36 to USD0.78 for one year. We proposed a revised price per seedling of USD1 for the first year, with an additional 10 cents per year for the following three years, to account for maintenance and labour costs. One-time projects that focus only on planting are likely to fail, especially without fire prevention management. Successful forest restoration projects should do more than simply planting trees by also including care and maintenance after they are planted. With this in mind, we provide a standardised framework to guide decision-making and successful forest restoration. Our results should help increase forest restoration success, improve sustainability and allow for the persistence of forested landscapes.
\end{abstract}

Keyword: Borneo, fire, fire management, weed management, restoration success, sustainability

\section{INTRODUCTION}

Tropical deforestation is a major cause of climate change (Gibbs \& Herold 2007). Deforestation causes up to a fifth of global $\mathrm{CO}_{2}$ emission (1.0-1.2 $\left.\mathrm{Pg} \mathrm{C}_{\text { year }}^{-1}\right)$ and thereby contributes to increasing global temperature (van der Werf et al. 2009). Projected emissions from deforestation in 2030 are the same as in 2004 (UNFCCC 2007). The primary causes of deforestation globally are subsistence agriculture $(48 \%)$, commercial agriculture or industrial plantations $(32 \%)$, logging-both legal and illegal (14\%), and the harvesting of fuel wood/charcoal $(5 \%)$ (UNFCCC 2007).

In contrast to global deforestation patterns, industrial plantations are the largest cause of tropical deforestation since the 1970s (Tsujino et al. 2016, Gaveau et al. 2019), followed by agriculture and wildfires induced by the El Niño-Southern Oscillation, which are further intensified by variability introduced by climate change (Latif et al. 2017, Carter et al. 2018). On the island of Borneo, for example, over half the original forest cover has already been cleared since 1970 to 2010 for industrial plantation, subsistent farming, wood export and wildfire (Gaveau et al. 2014). The remaining forest is degraded and fragmented due to selective logging and road building. Degraded forests still contain many trees but may be more vulnerable and have less conservation value (Costantini et al. 2016). Within protected areas, deforestation and degradation leads to biodiversity loss caused by habitat loss, fragmentation or genetic drift (Pardini et al. 2018). Groups of organisms respond differently to habitat changes (Costantini et al. 2016), but taken together disturbed forests may lose about $41 \%$ of animal species present in undisturbed habitats (Alroy 2017). The loss of species leads to subsequent changes in ecological processes like predation and pollination that are mediated by organisms. 
Gunung Palung National Park (GPNP) in West Kalimantan, Indonesian Borneo, is one of the largest remaining dipterocarp forests in Borneo with $\sim 70,000$ ha of intact forest, and is also the target of illegal timber extraction for commercial use. The GPNP is home to $5 \%$ of the global population of Bornean orangutans (Pongo pygmaeus wurmbii) (Johnson et al. 2005, IAR 2017). Since 1989, the GPNP has lost $10 \%$ of its forest because of logging and conversion to agriculture ( Zamzani et al. 2009, Yoshikura et al. 2016, Fawzi et al. 2018). This forest loss is partly due to a large number of people (up to $47-72 \%$ of households in some areas) who rely on illegal logging for their primary source of income (Hiller et al. 2004). Deforestation from logging and agriculture is exacerbated by wildfires associated with El Niño events. In recent years the government and NGOs have started projects to reduce and stop deforestation through smart patrols (spatial monitoring and reporting tool) and community empowerment community. However, the GPNP still contains over 10,000 ha of previously logged areas that have yet to regenerate into forest.

Reducing the rate of illegal deforestation is the best option for preserving the remaining forest cover. Following that, the next step is better forest management that both addresses the underlying socio-economic factors and includes reforestation to increase forest cover. Reforestation here refers to forest restoration that attempts to return previously cleared forest to its initial state, and is not to be confused with industrial forestry. Similarly, forest restoration is defined here as efforts to assist recovery of damaged forest ecosystems to their initial conditions. Forest restoration is thus not only about planting trees, but also includes a wide range of actions including forest protection, raising community awareness and caring for planted seedlings. Successful forest restoration thus requires us to define the target initial conditions and to modify plans to accommodate wildlife and socio-economic factors.

This holistic approach to forest restoration requires partnership between communities that are seeking sustainable livelihoods and the public institutions that manage the lands adjacent to their communities. Alam Sehat Lestari (ASRI) is a local NGO that works with communities and government agencies to incorporate these principles to fight deforestation and restore forests. In partnering with the GPNP office, they have established the overall objective of returning damaged forest within the park to its initial conditions. Together, ASRI and the GPNP office have conducted several forest restoration projects on damaged and degraded forest in the park. Here we reviewed the forest restoration projects and their success in GPNP, and analysed lessons learned from those projects.

\section{MATERIALS AND METHODS}

\section{Study area}

GPNP was first protected in 1937 with an area of $300 \mathrm{~km}^{2}$, and later expanded to a total of $1080 \mathrm{~km}^{2}$ in 2014 . It is located in two regencies, North Kayong Regency and Ketapang Regency, West Kalimantan $\left(01^{\circ} 03^{\prime}-01^{\circ} 22^{\prime} \mathrm{S}, 109^{\circ} 54^{\prime}-110^{\circ}\right.$ 28 ' E, Figure 1). The conservation area comprises seven ecosystems, which are subalpine forest, montane forest, lowland forest, heath forest, peatland forest, wetland forest and mangrove forest. The key animal species of conservation concern are Bornean orangutan with a park population of over 2500 individuals, proboscis monkeys (Nasalis larvatus), sun bears (Helarctos malayanus), marbled cat (Pardofelis marmorata), Sunda clouded leopard (Neofelis diardi), and helmeted hornbill (Rhinoplax vigil). The GPNP is also habitat for 3500-4000 identified plant species, including 70 tree species from the Dipterocarpaceae family (Setiawan \& Sofian 2018). These are represented primarily by five genera-Anisoptera, Dipterocarpus, Hopea, Shorea and Vatica (Curran \& Leighton 2000). The threatened Bornean ironwood (Eusideroxylon zwageri) is also abundant in the GPNP and has become a prime target for illegal logging activity (Kurokochi et al. 2015).

\section{Data and analysis}

To assess current conditions and lessons learned from forest restoration projects in GPNP, we collected data on every restoration project in the park. Early forest restoration programmes in GPNP were implemented either by ASRI or by the GPNP office and, thus, the restoration data used in this study were obtained from the GPNP office and from ASRI. In the restoration process, the GPNP office and ASRI work together with communities 


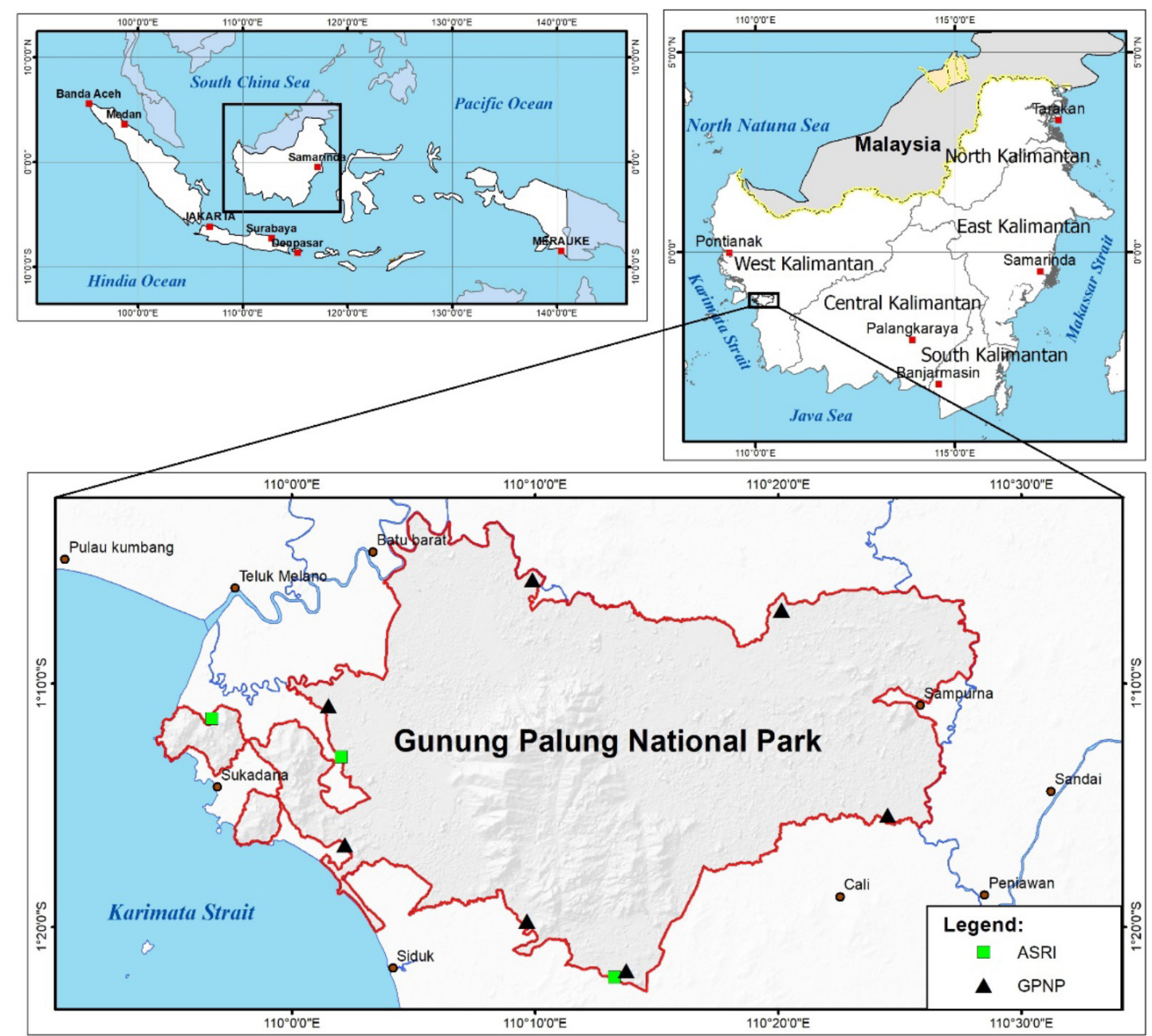

Figure 1 Study location in Gunung Palung National Park, Indonesia with the locations of restoration project area

for all restoration phases starting from care of seedlings, nursery, site preparation, planting and maintenance. In 2018, the GPNP office outlined a 5-year strategic plan for forest restoration that goes through 2023. In this strategic plan, the GPNP office includes an option for other stakeholders to participate in forest restoration. The GPNP has several degraded or grassland areas which need to be restored. Restoration projects are based on funding, accessibility and size of a potential site. The most important consideration is project location, because it is difficult to transport seedlings deep into the park.

ASRI and the GPNP office work together to restore the park, but they work separately regarding the technique, process and funding. For each restoration project, we collected data on the location of the project, its total area (in ha), seedling numbers (for calculating the seedling density per ha), and seedling survival rate. The data were collected from the GPNP office and ASRI. Data from the GPNP office were from the official restoration reports 2010-2014 of GPNP and report in 2018. The data from ASRI were annual restoration data after the planting season was over. Both the GPNP and ASRI discussed how to maintain consistency of data especially in measuring the same type of data. Survival rate was counted as the number of seedlings that survived after 1 year planting; this is to keep the data survival rate consistent and comparable. Interview with GPNP and ASRI staff was conducted to obtain additional information about forest restoration in GPNP, especially about fire management and monitoring programme. We then visited the restoration sites to assess and ground truth their recent conditions in 2019, including finding the cause of failure. We analysed the data to review forest restoration projects and their success in the park. 


\section{RESULTS}

\section{Forest restoration projects and their success in GPNP}

Despite the huge forest loss in the late 1990s, forest restoration was not previously a viable option due to constraint of resources. The GPNP resources focused on reducing logging and other illegal activities (such as hunting and farming) inside the park through smart patrols. In 2009, ASRI, in partnership with the US NGO Health in Harmony (supports funding of activities conducted by ASRI), began their first forest restoration project (Table 1 ). The following year in 2010, the GPNP office also started their first restoration project by replanting 200 ha in the sub-village of Pangkalan Jihing (Table 1, Figure 2).

ASRI's first forest restoration project focused on an area in the sub-village of Laman Satong (Figure 2). The area had previously been cleared by a timber concession operated by PT Marsela Wana Sekawan in late 1990s (Ode 2012), and was subsequently transformed by repeated wildfires into anthropogenic grassland (Imperata cylindrica). The restoration method involved planting a high density of seedlings (3100 seedlings per ha, spacing $1.7 \mathrm{~m}$ ). The high density helped to ensure the formation of canopy (1.8 $\mathrm{m}$ canopy diameter per seedling) within
2 years which reduced competition from weeds (Elliott et al. 2013).

This initial effort was met with several challenges. Low soil fertility of the degraded land due to compaction and erosion, often slowed seedling growth (Martínez-Garza et al. 2013). There were also setbacks from a severe anthropogenic wildfire in 2013 that burned almost $89 \%$ of the replanted area. The fire started from a wind-borne spark into the restoration area. At that time, nearby communities were using fire as a cheap and easy method to clear land. The fire spread to the restoration area, especially young areas recently planted in 2011-2012, and to adjoining dry grasslands which burned easily. ASRI continued to replant after the fire, and their method showed success after 5 years of planting and frequent weeding.

In 2013, ASRI started a second project to restore an orangutan dispersal corridor in the village of Sedahan Jaya (Figure 2). This project aimed to reforest an agricultural area which divided two forest fragments occupied by orangutans. Within 3 years of replanting, orangutan presence in the reforested area was confirmed by camera trap images (Figure 3). Finally, in 2018, ASRI stared its Garden to Forest Program, which aimed to rehabilitate small-scale farming areas inside the park. Small-scale farming existed before the national park was established (Salafsky 1994). These gardens are dominated

Table 1 Forest restoration conducted in Gunung Palung National Park (GPNP) by Alam Sehat Lestari (ASRI) and the GPNP office

\begin{tabular}{|c|c|c|c|c|c|c|c|c|}
\hline \multirow[t]{2}{*}{ Year } & \multicolumn{4}{|c|}{ Local NGO ASRI } & \multicolumn{4}{|c|}{ GPNP office } \\
\hline & $\begin{array}{l}\text { Total area } \\
\text { (ha) }\end{array}$ & $\begin{array}{l}\text { Seedlings } \\
(\text { No. })\end{array}$ & $\begin{array}{c}\text { Density } \\
\left(\mathrm{ha}^{-1}\right)\end{array}$ & Location* & $\begin{array}{l}\text { Total area } \\
\text { (ha) }\end{array}$ & $\begin{array}{l}\text { Seedlings } \\
(\text { No. })\end{array}$ & $\begin{array}{c}\text { Density } \\
\left(\mathrm{ha}^{-1}\right)\end{array}$ & Location* \\
\hline 2009 & 4 & $14,000 * *$ & 3100 & 7 & - & - & - & \\
\hline 2010 & 6 & $26,550 * *$ & 3100 & 7 & 200 & 80,000 & 400 & 6 \\
\hline 2011 & 7 & $22,179 * *$ & 3100 & 7 & 2,530 & 940,000 & 400 & 4,8 \\
\hline 2012 & 2 & 7350 & 3675 & 7 & 1,000 & 80,000 & 80 & $5,2,9$ \\
\hline 2013 & 7 & 15,986 & 2284 & 7,3 & 900 & 150,000 & 166 & 8,4 \\
\hline 2014 & 3 & 6546 & 2182 & 7,3 & 200 & 120,000 & 600 & 6 \\
\hline 2015 & 2.5 & 5456 & 2182 & 7,3 & - & - & - & \\
\hline 2016 & 4 & 9432 & 2358 & 7 & - & - & - & \\
\hline 2017 & 8.5 & 19,849 & 2335 & 7,1 & - & - & - & \\
\hline 2018 & 47 & 47,140 & 1003 & 7,1 & 10 & 6000 & 600 & 10 \\
\hline Total & 91 & 174,488 & & & 4840 & $1,376,000$ & & \\
\hline
\end{tabular}

*Location numbers refer to map in Figure 2; **includes enrichment planting 


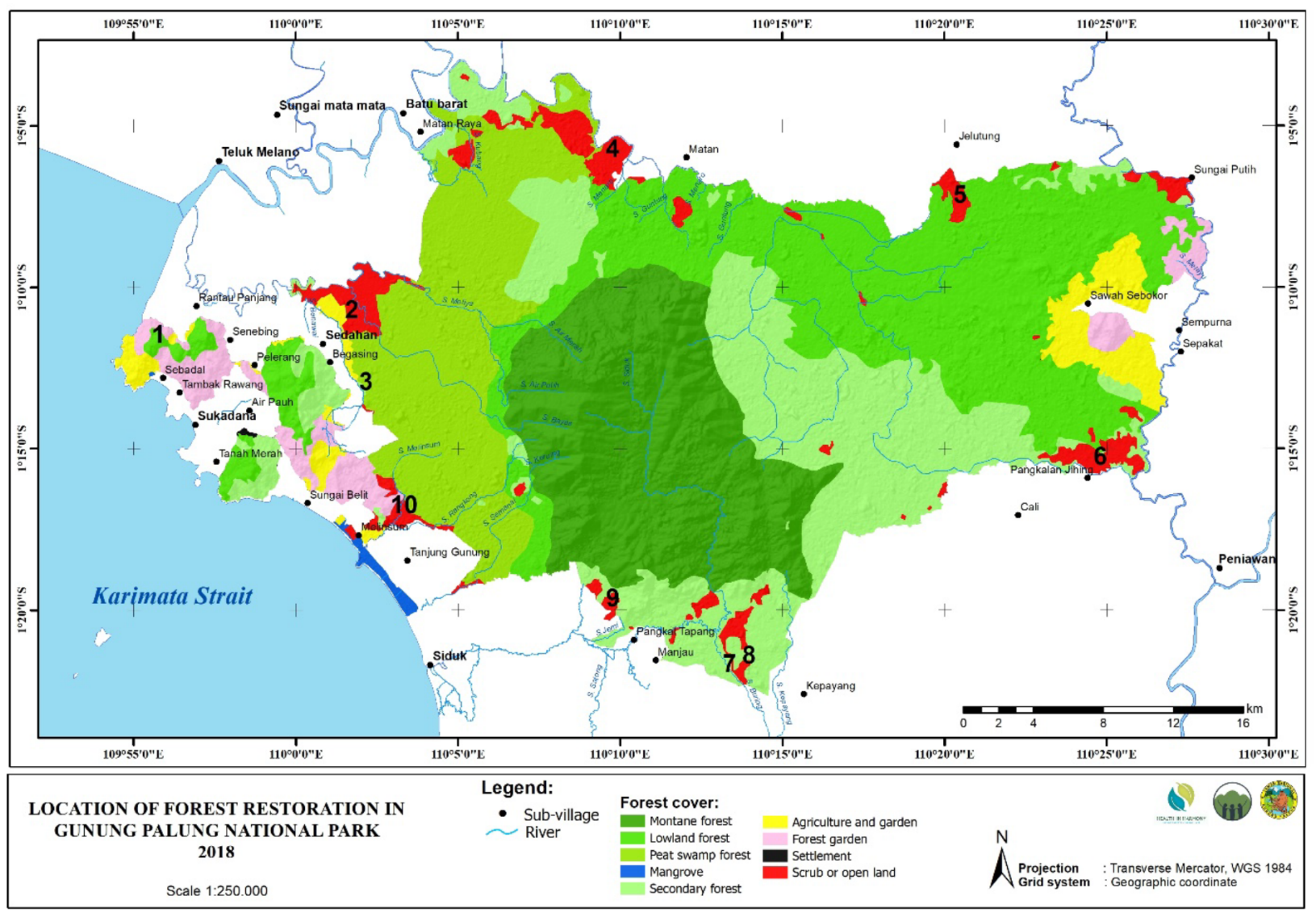

Figure 2 Forest cover and restoration locations (numbers 1-10) in Gunung Palung National Park; red and yellow are areas which need restoration
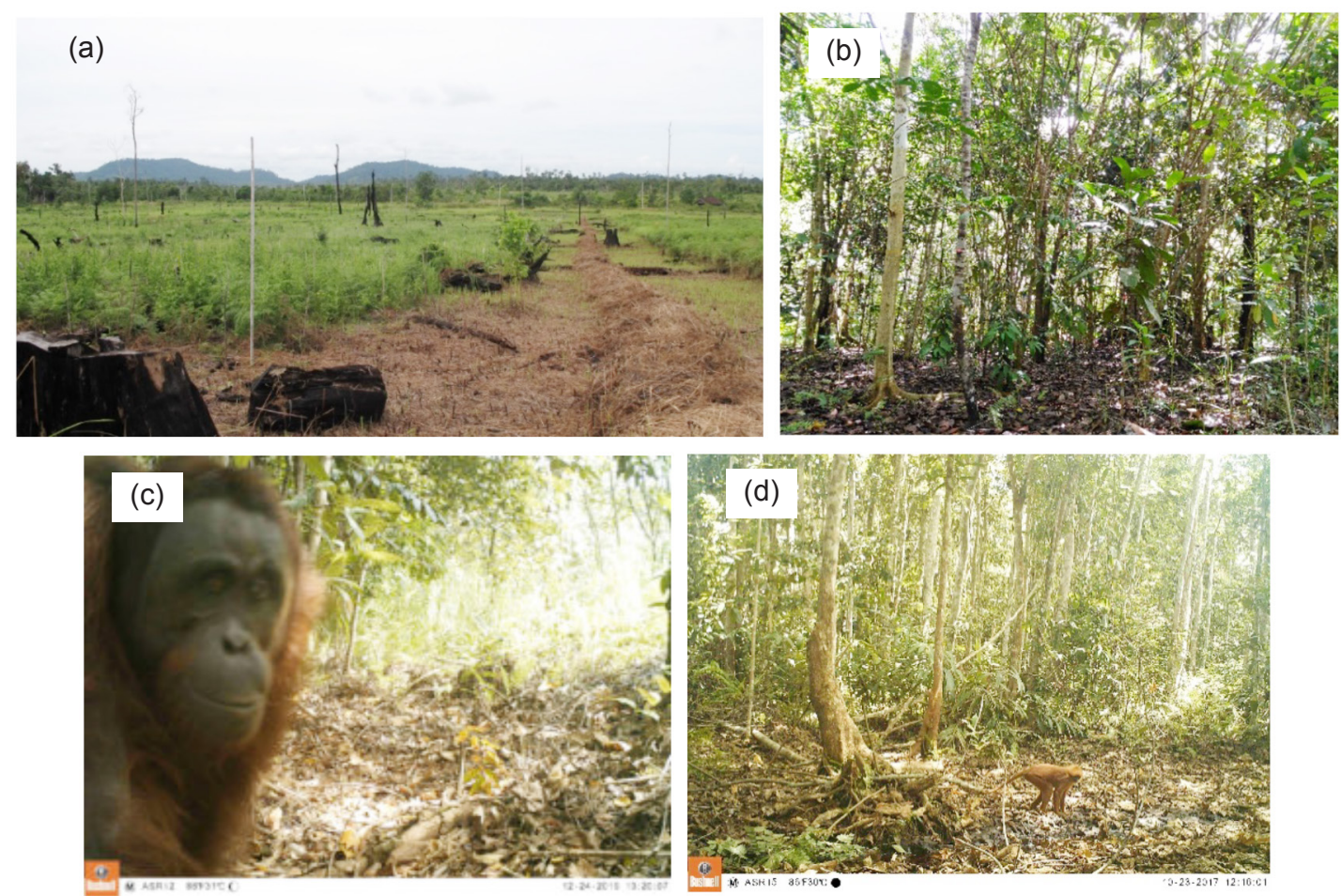

Figure 3 (a) Before (2009) and (b) 10 years after planting in one of ASRI's reforestation sites; the presence of wildlife animal (c) Bornean orangutan and (d) red leaf monkey Presbytis rubicunda) at ASRI reforestation sites 
by durian trees (Durio zibethinus) and associated with the slash and burn activity for farming chilis, bananas and vegetables. Even though the gardens are a previously existing landuse, communities often cut trees and burn in the park to start new gardens, contributing to deforestation. The project has successfully gained the trust and involvement of local communities which have committed to a conservation agreement. In its first phase in 2018, 39 ha were planted. Building on this success, the programme has expanded and aims to eventually involve 100 community members and more than 250 ha of rehabilitated area.

The GPNP office, on the other hand, is a government institution bound by many regulations and strict budgeting. The GPNP office started the restoration project one year behind ASRI. Although they replanted 4840 ha spread over seven reforestation sites, their budgets only included the cost of planting and allowed for no follow-up maintenance. Without fire prevention activity, most of the restoration areas burned in wildfires during the El Niño events in 2013 and 2015. The evaluation after wildfires prevented any restoration project by GPNP office in 2016 through 2017. The burned areas failed to regenerate into forest and are still in need of restoration. Since the park office used a low-density method with 4 or $5 \mathrm{~m}$ planting distances, with no following intervention, the seedlings were outcompeted by weeds and failed to create a canopy. Budget restrictions also precluded the appropriate preparation of seedlings before planting. Restoring some wetland areas, for example, requires the planting of seedlings at least 1-m tall, which is not possible within 1-year programme budgets. The 1-m height allows seedlings to survive rainy seasons, when wet areas can be temporarily flooded by water $50-100 \mathrm{~cm}$ deep.

Measuring the success of tropical forest restoration was quite tricky and required us to define the programme goals. For general purposes, we used seedling survival rates to evaluate programme success. Programmes are considered successful if the seedling survival rate is above $70 \%, 2$ years post-planting and are considered failures if the rates are below $45 \%$ (Elliott et al. 2013). Projects with intermediate survival rates between 50 and $70 \%$ are still acceptable. Survival rates must also be accompanied by a minimum plant height of $2 \mathrm{~m}$ after 2 years planting. After years of developing planting methods, ASRI's average seedling survival rate over the years 2014-2018 was up to $81.2 \%, 1$ year after planting. ASRI supplements surviving seedlings by conducting enrichment planting to replace seedlings that die early. Enrichment planting consisted about $10 \%$ of the number of seedlings that have already been planted. This process can boost the effective seedling survival rate 2 years after planting to $90 \%$. For the national park office, reports showed average seedling survival rate was $85.1 \%, 1$ year after planting. The following year a wildfire burned most of the restoration area. In the future, we recommend adding 'no fire occurred in the forest restoration area' as another criterion to evaluate programme success, not just survival rate.

\section{Lessons learned from restoration projects}

We highlighted failed restoration projects in Gunung Palung National Park to learn ways to improve project success in future. In Indonesia, forest restoration programmes are under the jurisdiction of the Ministry of Forest and Environmental (MoFE). MoFE gives permits for all restoration projects in protected areas or may reject them if they do not meet the criteria for ecosystem benefits. After the failure of a national programme aiming to plant 1 billion Indonesian trees (Hadi 2017), MoFE now focuses on restoration success rather than the sum total of trees planted. The first phase of this new approach was to make a 5-year strategic plan for ecosystem recovery for every protected forest in Indonesia. Although the GPNP office has already planted almost $5000 \mathrm{ha}$, the plan for ecosystem recovery for the park (2018-2023) still mandates a recovery of another 4559 ha in which includes the failed projects that have already been planted. Closing that gap will require GPNP and NGOpublic partnerships (including ASRI) to resolve several issues. Here we describe issues and lessons from previous restoration projects in GPNP.

The primary issue for forest restoration is anthropogenic wildfire. Although restoration projects conducted by the GPNP office have an initial seedling survival rate of over $80 \%$, all of the planting sites have been subsequently burned. This is caused by the absence of adequate maintenance and fire prevention. ASRI, in contrast, combines high-density planting with 
fire prevention activity, but even so one of their sites suffered a severe wildfire that burned 19 ha in 2013. All these fires were triggered by human activity. Although the fires were not intended to burn the restoration sites, they spread into them. Wildfires peaked during the dry season when people burned land for agriculture, and were exacerbated by drought, especially during the 2015 El Niño year (Taufik et al. 2017). Fire prevention is thus a main task for organisations conducting forest restoration.

The second issue is the effect of weed competition on seedling growth. Regenerating forest must have at least 5-m canopy height to be considered forest and $82.2 \%$ canopy cover to prevent the growth of competing weeds (Cao et al. 2017). ASRI's oldest restoration sites have already solved this problem because they have sufficient canopy cover and leaf litter deposition to eliminate weeds. Regular weeding can solve this problem. In contrast, in projects managed by the park office, even some unburned reforestation areas often fail to grow because seedlings do not form sufficient canopy cover, causing competition with weeds. This is because of two reasons, namely, all the planted seedlings are slow-growing tree species and they are spaced too far apart. All the tree species planted by the park office are slow-growing trees such as meranti (Shorea spp.), durian and nyatoh (Palaquium spp.). This is partly because regulations stipulated by the MoFE require that $90 \%$ of planted seedlings to be woody native species. The remaining $10 \%$ are often slowgrowing fruit trees. We suggest that it is more important to provide an adequate mix of slowand fast-growing species, rather than focusing on the 90:10 native:fruit tree ratio. The Garden to Forest Program uses a native fast-growing leguminous tree (Archidendron pauciflorum) to accelerate establishment of canopy cover and fruit production. In addition, the standard spacing of 3 to $5 \mathrm{~m}$ between seedlings is too far apart for optimal forest restoration (ITTO 1993, Kettle et al. 2011, Cao et al. 2017). In lowdensity plantings like this, even plants that are not burned succumb to competition with weeds because seedlings are too far apart to form a closed canopy.

The third issue is failure to budget enough money per seedling. The national park office currently budgets USD 0.78 per seedling. Previously this price was even lower, at USD0.36.
ASRI, in contrast, has always estimated a price per seedling of around USD1, and an additional USD0.10 per year to accommodate maintenance (weeding and fire prevention). The cost is to cover all activity during the forest restoration project, including nursery, seedling preparations, transporting seedling, planting, weeding and fire prevention. Maintenance is the biggest oversight in restoration funding. Restoration failures are mostly due to lack of maintenance, especially weeding and fire prevention.

Finally, the fourth issue is failure to define a restoration strategy. Restoration strategies should at the least use different methods in different ecosystems. Previous restoration projects, in contrast, have often applied a single strict method to be followed in all cases, especially in government projects. In GPNP and other areas in West Kalimantan, for example, it is common to use sungkai (Peronema canescens) in all restoration projects. However, we have found that sungkai is not suitable for restoration in lowland forest areas and does not provide adequate canopy. ASRI restoration projects have therefore reduced their use of this species. Forest restoration thus requires knowledge about the restoration site, which can be used to select an appropriate restoration method.

Before selecting a method, we need to assess the level of forest damage. The level of forest damage is grouped into stages ranging from partial canopy loss to cleared forest that has been converted into barren land (Elliot et al. 2013, Table 2). Understanding the damage stage is important for choosing an appropriate forest restoration strategy and method. For lightly damaged forests in stages 1 and 2, we can use forest protection or natural regeneration, or accelerated natural regeneration and agroforestry. Forest protection refers to preserving what is left of the degraded forest so as not to increase damage and to allow succession to proceed. The aim is to prevent further forest loss from activities such as subsistence farming, pollution, logging, or expanding development, and to allow recovery from previous forest loss. Forest protection is a wide approach that ranges from law enforcement to sustainable management that includes socioeconomic factors. This protection will boost natural forest regeneration. If the damage is too extreme or take too long to recover on its own, accelerated natural regeneration is an option. Accelerated natural regeneration involves low- 
Table 2 Stages of forest damage and restoration options*

\begin{tabular}{|c|c|c|}
\hline $\begin{array}{l}\text { Level of } \\
\text { damage }\end{array}$ & Description & Options for restoration \\
\hline
\end{tabular}




density plantings of particular species for specific purposes. Agroforestry, meanwhile, may provide alternative livelihoods from reforestation. The main driver of deforestation in GPNP is conversion to agriculture (Yoshikura et al. 2016, Zamzani et al. 2009), so incorporating socioeconomic factors into restoration projects will increase the future benefits to the forest. If forest is severely damaged, planting seedlings at high densities with appropriate follow up maintenance is the best option.

Understanding the restoration strategy allows us to understand what appropriate species must be planted and how. Forest restoration is an experiment. No one method will always give a higher probability of success. Formulating a strategy is a crucial part of planning forest restoration programmes. Most failed restoration programmes result from a lack of planning and maintenance activity.

\section{DISCUSSION}

Forest restoration aims to restore damage ecosystems to their initial conditions. This process will help us sustainably live on earth by balancing deforestation with restoration. Forest restoration is a hard and we pay for our mistakes through the consequences of deforestation. We cannot afford additional mistakes during forest restoration. How can we ensure success in forest restoration?

It is essential to make sure the restoration strategy matches the site, including species selection, planting time (e.g. during the wet season), and project timeline. Small targeted projects with intensive maintenance are often more successful than projects planted over large areas. In the process of restoration project, underlying socio-economic factors are essentials in returning the forest ecosystem. The community involvement can be in many ways, including employing local people in restoration programmes. Both the GPNP office and ASRI employ local people, and intensive engagement may increase their awareness and concern about the forest (Pohnan et al. 2015). ASRI also has a clinic where patients who do not have money can pay with items that will be used in conservation projects such as plant seedlings, manure or traditional mats. The seedlings will later be planted in ASRI's reforestation areas.
In the oldest ASRI restoration site, the community can harvest fruit trees from seedlings they planted. Building community awareness brings a sense of belonging to forest. Long-term involvement will help in protecting the restoration site especially from wildfire prevention.

Monitoring forest restoration sites, including the growth of planted seedlings and the presence of wildlife, is also important. The seedling growth parameters are basal root diameter, vegetation height, tree density, species richness, and identification of plants that grow naturally (Viani et al. 2018). For wildlife monitoring, camera traps or field surveys may be used to monitor wildlife presence. Biomonitoring efforts in ASRI's oldest reforestation site, for example, documented the return of 70 native bird species, an approximately eightfold increase from a low of eight species when planting started (Helms et al. 2018).

\section{CONCLUSIONS}

It is difficult to successfully restore forests. Since 2009 , almost 5000 ha of damaged forest in GPNP have been replanted without the desired ecosystem results. Most of the 4559 ha which still need restoration under the mandatory plan for ecosystem recovery are within existing restoration areas that have been burnt. GPNP use seedling survival rate as a definition of success and using only this definition, all restoration projects had survival rates of $>80 \%$. But this measurement was only for the first year, and in the following years most of the planted areas were burnt by severe wildfires. The fundamental factor in project success is maintenance (weeding) and fire prevention. Successful forest restoration requires planning and budgeting for multiple years, from the planting of seedlings until their growth into trees. We suggest budgeting a price per seedling around USD1 for the first year of planting, with maintenance and community labour adding USD0.10 per seedling in the following years. We cannot afford further mistakes in forest restoration. To restore damaged ecosystems in GPNP, we need a massive forest restoration programme with a standard strategic framework.

\section{REFERENCE}

Alroy J. 2017. Effects of habitat disturbance on tropical forest biodiversity. Proceedings of the National Academy of Sciences of the United States of America 114: 60566061. https://doi.org/10.1073/pnas.1611855114. 
Cao S, Lu C \& Yue H. 2017. Optimal tree canopy cover during ecological restoration: a case study of possible ecological thresholds in Changting, China. BioScience 67: 221-232. https://doi.org/10.1093/ biosci/biw157.

Carter S, Herold M, Avitabile V et al. 2018. Agriculturedriven deforestation in the tropics from 19902015: emissions, trends and uncertainties. Environmental Research Letters 13: 014002. https:// doi.org/10.1088/1748-9326/aa9ea4.

Costantini D, Edwards DP \& Simons MJP. 2016. Life after logging in tropical forests of Borneo: a meta-analysis. Biological Conservation 196: 182-188. https://doi. org/10.1016/J.BIOCON.2016.02.020.

Curran LM \& Leighton M. 2000. Vertebrate responses to spatiotemporal variation in seed production of mastfruiting Dipterocarpaceae. Ecological Monographs 70: 101-128. https://doi.org/10.1890/00129615(2000)070[0101:VRTSVI]2.0.CO;2.

Elliott SD, Blakesley D \& Hardwick K. 2013. Restoring Tropical Forests: A Practical Guide. Kew Publishing, Royal Botanic Gardens, Kew, Richmond.

Fawzi Ni, Husna VN \& Helms JA. 2018. Measuring deforestation using remote sensing and its implication for conservation in Gunung Palung National Park, West Kalimantan, Indonesia. IOP Conference Series: Earth and Environmental Science 149: 012038. https://doi.org/10.1088/17551315/149/1/012038.

Gaveau Dla, Locatelli B, Salim MA, Yaen H, Pacheco P \& SHEIL D. 2019. Rise and fall of forest loss and industrial plantations in Borneo (2000-2017). Conservation Letters 12: 1-8. https://doi.org/10.1111/conl.12622.

Gaveau DLA, Sloan S, Molidena E et al. 2014. Four decades of forest persistence, clearance and logging on Borneo. PLoS ONE 9. https://doi.org/10.1371/ journal.pone.0101654.

Gibbs HK \& Herold M. 2007. Tropical deforestation and greenhouse gas emissions. Environmental Research Letters 2: 045021. https://doi.org/10.1088/17489326/2/4/045021.

Hadi U. 2017. Jokowi Sentil Kementerian LHK: Tanam 1 Miliar Pohon, yang Tumbuh 6 [WWW Document]. https://news.detik.com/berita-jawatengah/d-3776896/jokowi-sentil-kementerian-lhktanam-1-miliar-pohon-yang-tumbuh-6. (Accessed 18 October 2019)

Helms JA, Woerner CR, Fawzi NI et al. 2018. Rapid response of bird communities to small-scale reforestation in Indonesian Borneo. Tropical Conservation Science 11: 1-8. https://doi.org/10.1177/1940082918769460.

Hiller ma, Jarvis BC, Lisa H, Paulson LJ, Pollard EHB \& Stanley SA. 2004. Recent trends in illegal logging and a brief discussion of their causes: a case study from Gunung Palung National Park, Indonesia. Journal of Sustainable Forestry 19: 181-212. https:// doi.org/10.1300/J091v19n01_09.

IAR (International Animal Rescue). 2017. Orangutan Density Survey in Gunung Palung National Park, West Kalimantan. Yayasan IAR Indonesia and the Borneo Nature Foundation, Ketapang.

ITTO. 1993. Rehabilitation of Logged-Over Forest in Asia/Pacific Region. International Tropical Timber Association, Yokohama.
Johnson AE, Knott CD, Pamungkas B, Pasaribu M \& Marshall AJ. 2005. A survey of the orangutan (Pongo pygmaeus wurmbii) population in and around Gunung Palung National Park, West Kalimantan, Indonesia based on nest counts. Biological Conservation 121: 495-507. https://doi.org/10.1016/J.BIOCON.2004.06.002.

Kettle CJ, Ghazoul J, Ashton P et al. 2011. Seeing the fruit for the trees in Borneo. Conservation Letters 4: 184-191. https://doi.org/10.1111/j.1755263X.2010.00161.x.

Kurokochi H, Nurtjahjaningsih ILG, Sukartiningsih et al. 2015. Development of polymorphic chloroplast DNA markers for the endangered tree Eusideroxylon zwageri through chloroplast isolation and next-generation sequencing. Conservation Genetics Resources 7: 845850. https://doi.org/10.1007/s12686-015-0485-8.

Latif MT, Othman M, Abdullah AM, Khan MF, Ahamad F \& Juneng L. 2017. Southeast Asian forest fires $(1997 / 1998)$ : El Niño as a driver of regional impacts $\mathrm{Pp}$ 191-225 in Brimblecombe P (ed) Air Pollution Episodes. World Scientific Publishing Europe Ltd., London. https://doi. org/10.1142/9781786343413_0011.

Martínez-Garza C, Tobon W, Campo J \& Howe HF. 2013. Drought mortality of tree seedlings in an eroded tropical pasture. Land Degradation and Development 24: 287-295. https://doi.org/10.1002/ldr.1127.

OdE MDL. 2012. Etnis Cina Indonesia dalam Politik: Politik Etnis Cina dan Singkawang di era Reformasi 1998-2008. Yayasan Pustaka Obor Indonesia, Jakarta.

Pardini R, Nichols E \& PÜtTKer T. 2018. Biodiversity response to habitat loss and fragmentation. Pp 229-239 in DellaSala D \& Goldstein M (eds) Encyclopedia of the Anthropocene. Elsevier Inc., Oxford. https://doi. org/10.1016/B978-0-12-809665-9.09824-4.

Pohnan E, Ompusunggu H \& Webb C. 2015. Does tree planting change minds? Assessing the use of community participation in reforestation to address illegal logging in West Kalimantan. Tropical Conservation Science 8: 45-57. https://doi. org/10.1177/194008291500800107.

SAlafsky N. 1994. Forest gardens in the Gunung Palung region of West Kalimantan, Indonesia. Agroforestry Systems 28: 237-268. https://doi.org/10.1007/ BF00704759.

Setianan E \& Sofian D. 2018. Gunung Palung National Park Living In Harmony. Gunung Palung National Park, Ketapang.

Taufik M, Torfs PJJF, Uijlenhoet R, Jones PD, Murdiyarso D \& VAN LANEN HAJ. 2017. Amplification of wildfire area burnt by hydrological drought in the humid tropics. Nature Climate Change 7: 428-431. https:/ / doi.org/10.1038/nclimate3280.

Tsujino R, Yumoto T, Kitamura S, Djamaluddin I \& Darnaedi D. 2016. History of forest loss and degradation in Indonesia. Land Use Policy 57: 335-347. https://doi. org/10.1016/j.landusepol.2016.05.034.

UNFCCC. 2007. Investment and Financial Flows to Address Climate Change. United Nations Framework Convention on Climate Change. United Nations Framework Convention on Climate Change, Bonn.

van der Werf GR, Morton DC, DeFries RS et al. 2009. $\mathrm{CO}_{2}$ emissions from forest loss. Nature Geoscience 2: 737-738. https://doi.org/10.1038/ngeo671. 
Viani RaG, Barreto Te, Farah FT, Rodrigues RR \& BRANCALION PHS. 2018. Monitoring young tropical forest restoration sites: how much to measure? Tropical Conservation Science 11: 1-9. https://doi. org/10.1177/1940082918780916.

Yoshikura T, Amano M, Wardhana D \& Supriyanto B. 2016. Identifying the agents and drivers of deforestation: an examination around Gunung Palung National
Park, West Kalimantan, Indonesia. International Journal of Agricultural Resources, Governance and Ecology 12: 327-343. https://doi.org/10.1504/ ijarge.2016.10001702.

Zamzani F, Onda N, Yoshino K \& Masuda M. 2009. Deforestation and agricultural expansion processes in Gunung Palung National Park, West Kalimantan, Indonesia. Jurnal Manajemen Hutan Tropika 15: 24-31. 